\title{
Pasi Hirvonen
}

University of Eastern Finland, Finland

DOl: https://doi.org/10.18778/1733-8077.9.4.05

\section{Positioning in an Inter-Professional Team Meeting: Examining Positioning Theory as a Methodological Tool for Micro-Cultural Group Studies}

Abstract This paper sets out to test the possibilities of the Positioning Theory as a means to approach small group phenomena from a micro-cultural perspective. The study draws on a transcription of a videotaped inter-professional team meeting in the field of social services. Analysis of the data was set to examine how the basic concepts of the Positioning Theory suit the analysis of in-group phenomena, what different forms of positioning are present, and how the positioning is connected to the group processes. Studying the group's interaction shows how it is possible to approach the interaction via the basic concepts of the Positioning Theory and how the positioning is intervened with group processes, such as decision-making, arguing, and conflict. The study also offers a new theoretical and empirical perspective to the research on small group dynamics.

Keywords Positioning Theory; Positioning; Group; Interaction; Micro-Cultural

Pasi Hirvonen is a postgraduate student of Social Psychology in the Department of Social Sciences at the University of Eastern Finland. The working title of his doctoral dissertation is Positioning Theory and group dynamics: Positioning in management board meetings, and it focuses on discursive positioning in decision-making and conflict situations in small groups. His fields of interest include small group and interaction studies and qualitative methods

email address: pasi.hirvonen@uef.fi
The aim of the study presented in this article is to examine the possibility of adapting the basic concepts of the Positioning Theory to the field of micro-culturally oriented group studies. The theory was originally developed by Rom Harré and Luk van Langenhove (1999a) as a means to understand the dynamic nature of social episodes and human interactions.

The perspectives arising from the linguistic turn in the social sciences can be regarded as the standing point of the Positioning Theory. The dualism between the cognitive or experimental research methods, predating the more critically and discursively oriented views taken up by the linguistic turn in the 1960s and 1970s, exemplifies the somewhat two-fold nature of social psychological research. The linguistic turn can be viewed as a turning point in social sciences as it gave way to a new era of research based on its criticism against the individually oriented experimental traditions (see Potter and Wetherell 1987; Gough and McFadden 2001).

Dualism of two different methodological and epistemological standpoints is also visible in the field of group studies. The epistemological standpoints of this field can roughly be divided into two different approaches - the cognitive, or experimental, and the psychodynamic one - both of which include various perspectives and empirical orientations (see Poole and Hollingshead 2004; Poole et al. 2004). The first focuses on how the individual cognition, such as perception, and processes of action are connected to the social realm via group membership and vice versa. The latter emphasizes the unconscious motives of human behavior, also as a basis for the functioning of groups adopting views and concepts from the psychoanalytic tradition. During the past two decades, groups have also been approached from a more cultural perspective (see e.g., Hartley 1997:29-31; Denzin 1999:308-310), and these approaches can be viewed as a third predominant approach to group studies. However, the amount of interest in groups in micro-sociological and social-psychological research in general has varied over the past six or seven decades, and in recent years more emphasis has been put on intergroup relations (see de Moura et al. 2008; Wittenbaum and Moreland 2008). One of the many reasons of why so few attempts to find new perspectives to group studies have been made is a methodological one. New and current methodological approaches have not been available or have not yet been adapted to the current issues dealing with the multiple ways of viewing groups and their dynamics.

In this study, the cultural perspectives on groups are referred to as micro-cultural group studies. These perspectives stem mostly from views of sociality in phenomenological sociology, American micro-sociology, and social psychology; also, they are present in social constructionists' thought (see e.g., Potter and Edwards 2001; Delamater 2003). The studies on culture, interaction, and context, as wel as norms, roles, social networks, and other microcultural phenomena as means of understanding the social behavior have gained particular interest (see Burke 2003; Rohall, Milkie, and Lucas 2007). To an extent, the cultural interpretations view human behavior and experience of individuality as something constructed in the course of everyday interaction, different relationships, and being a member of different kinds of social groups. With this perspective in mind, the study of the rule-governed nature of human behavior and the study of how individuals interpret these rules and the actions of others has gained much emphasis.

The study of social interaction - with its long and extensive history - is one of the pivotal segments of micro-cultural studies. One of the most recognizable and influential views on interaction is Robert F. Bales' (1951) interaction process analysis (IPA). In addition to IPA, objects of group studies within this field have dealt with concepts of status, power, and leadership, as well as integration and 
cohesion (Burke 2003; see also Rohal, Milkie, and Lucas 2007). Studying meetings and interactions, as well as institutional interactions (see e.g., Kangasharju 2002; Heritage 2004; Arminen 2005), is not all that new, especially, in the field of economics and management (see e.g., Asmu $\beta$ and Svennevig 2009). Meetings and negotiations, as well as communication in small groups, have also been examined from the viewpoint of organizational ethnography (see e.g., Schwartzman 1989) and conversation analysis (see e.g., Firth 1995). However, most of the critical approaches, such as the study of interactions or culture, have not yet been adapted to the in-group context to the same extent as the views represented by the two more well-known paradigms. Consequently, the basic concepts of the Positioning Theory have not been adapted to a small group level to the same extent as to the interpersonal or intergroup level.

\section{The Positioning Theory and}

Micro-Cultural Group Studies

Rom Harré, one of the father figures of the Positioning Theory, sees the social reality as principally consisting of rule- and convention-governed models of cooperation, as well as joint actions (Harré 1997). The Positioning Theory is something that strives to explain the dynamic nature and the moral aspects of social behaviour within its complexity, locality, temporality, and cultural context of thought and language. According to this "dynamic paradigm" (e.g., Harré and Moghaddam 2003:3), more emphasis should be laid on the analysis of social interaction episodes than on experimental studies; also, the analysis of these episodes should focus on the situation specific meanings and roles which are both constructed during particular epi- sodes embedded within a specific situational context. The Positioning Theory - as a study of socia interactions developed within local moral orders - focuses on the moral rights and duties of interlocutors. The analysis of one's authority to speak and take part in the interaction, as well as how these authorities, rights, and duties are distributed amongst people taking part in a particular interaction, constitutes the starting point of the theory at hand (Harré and van Langenhove 1999a:1). The use of the term "position" varies; so far, it has been used in many different ways and many different contexts regarding the field of (Social) Psychology and Sociology. More recently, it has been viewed as a more dynamic perspective of the rather static concept of the role. Whereas roles remain relatively static from one situation to another, situation specific positions are more dynamic - as guided by one's rights and duties. Nowadays, the concept at hand is most commonly associated with the study and analysis of ever developing and symbolically mediated interaction, with the focus on both the individual- and group-related aspects of interaction (see e.g., Frosh, Phoenix, and Pattman 2003; Sammut and Gaskell 2010). This makes the nature of concepts like position and positioning more suitable for the analysis of interaction and its dynamics than more static concepts, for instance, that of the role (see Harré and Slocum 2003:126-127).

Positioning as action, or an act, refers to the determination and discursive construction of familia "parts" and "roles" of the speakers, which make one's actions and the social episodes intelligible and reasonable. For instance, in a conversation between a teacher and a student the right to make certain remarks is differently committed between the two parties to an interaction. The same utter- ance gets a different social meaning depending on which of the interlocutors expresses it. The different utterances and speech-acts then reveal the storylines characterizing the conversation (van Langenhove and Harré 1999:17). According to Harré and van Langenhove, the dynamics of the previous example can be presented as a figure referred to as the positioning triangle.

Figure 1. The positioning triangle.

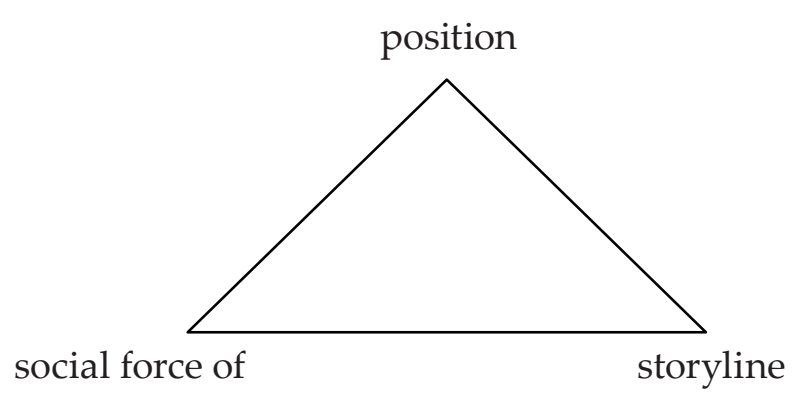

Source: van Langenhove and Harré (1999a:18).

In this context, position refers to the collection of rights and duties of a person (or a group) to perform certain acts. The shared presumptions of personal attributes, leading to the expectation of certain kinds of behavior, are both distributed and constructed on the discursive level. All social situations and environments create possibilities for positioning where different positions can be adopted, contended, or forced in a dynamic way. Social force, or social action, includes all the ongoing talks and activities that should be revised as meaningful actions and performances. These actions take place in different episodes, simultaneously constituting the episodes, as well as the ongoing storylines. Also, previous experiences of the interlocutors are key features guiding the episodes. The storyline refers, thus, to the patterns of functioning within the given ongoing episode which is based on previous episodes (see e.g., Harré and Moghaddam 2003:5-6). More specifically, the concept of storyline refers here to the sequences of verbal interactions and their specific nature. For example, a short discussion between a doctor and a patient could be viewed as a storyline of consultation, and that between a teacher and a student as a storyline of tutoring. Hence, storylines can be viewed in this context as an abstract, or a summary, of the ongoing interaction.

The layout presented in the positioning triangle can take place on both an interpersonal and an intergroup level, as well on an inter-institutional level when each of the triad's basic concepts is set in its own context. A review of the studies applying the theory at hand illustrates the same perspectives, emphasizing the study on a person-to-person communication level, intergroup level interaction, and communication and interaction on a more cultural level (see Harré and van Langenhove 1999b; Harré and Moghaddam 2003). Positioning on an interpersonal level has also been approached from a narrative perspective (see e.g., Hydén 2005) - by illustrating the construction of individual agency in relation to different positions. More recently, the theory in question has been adapted, for example, to understand the Internet discourse and to - theoretically - develop a broader framework for the analysis of discourse in general in the social sciences (Schmidle 2010; Slocum-Bradley 2010; see also Linehan and McCarthy 2000), as well as to the analysis of close relationships and broader cultural and political phenomena, as well as intra-personal and inter-group positioning (Moghaddam, Hanley, and Harré 2003; Harré and Moghaddam 2008). However, the intra-group aspects of interaction and positioning, as presented in the Positioning Theory, have been somewhat left aside. 
Positioning can be viewed as something that has consequences and is a part of the everyday interaction. Approaching group interaction from this viewpoint facilitates more detailed examination of the dynamics of interaction than, for example, interaction process analysis and other quantifying methods of interaction analysis.

\section{The Aims of the Current Study}

The present study aims to examine the possibilities of the Positioning Theory as a means to approach small group interaction and performance through the micro-cultural perspective. To reach the aims of the micro-cultural perspective, a natural group was considered most suitable for the study at hand. Hence, it wouldn't serve its intentions if the group under scrutiny was formed just to achieve the research purposes. With this in mind, inter-professional teams form one interesting and current example. Research concerning inter-professional working methods is of a particular interest in the field of organizational behavior and group decision-making, and the data used in this study also come from this field. Studying meetings and interactions, the focus has usually been on institutional interactions and the method of choice has usually been conversation analysis.

\section{The aims of the study are as follows:}

1. What different forms of positioning are present in the in-group interaction? How do the basic concepts of the Positioning Theory suit the analysis of in-group phenomena?

2. How, if at all, is the positioning connected to the in-group processes, such as negotiating, decision making, and conflict?
3. How do the basic concepts of the Positioning Theory suit the analysis of in-group phenomena?

\section{Method}

This article draws on analyses based on videotaped material and examples from a study led by Pirjo Nikander ${ }^{1}$ (see 2003; 2005) dealing with argumentation and rhetoric decision-making processes during the inter-professional meetings. This pape draws on observations of a 1-hour-long material of an almost 3-hours-long meeting dealing with elderly or disabled clients' home care benefits.

The function of the meeting is to make the multiprofessional case specific decisions about elderly care and home help services. The meeting at hand took place in a small conference room where everyone was seated around an oval-shaped table. The participants were seated in such a way that everyone could see each other. Altogether, eleven socia and health care professionals participated in the meeting. The group included a doctor, a secretary of care giving, six home help services directors, and six nurses. The doctor was facing the secretary on the right hand side and the others surrounded them. Every participant had documents in front of him/her, and at the beginning of the meeting the doctor collected the medical statements concerning the cases at hand. The secretary also had al the cases related documents. The participants represented their own specific points of view and expertise, as well as case specific knowledge regarding each of the cases discussed. The home help ser-

Academy of Finland funded this research project (Constructing Age, Health, and Competence. Argumentation and Rhetoric in Institutional and Personal Discourse). The data were collected between 2001 and 2002 and consist of 42 hours of videotaped material or meeting in vices directors and the nurses have firsthand information on the cases - since they are the ones who have been in contact with the clients most recently. The meeting can be described as semi-official by its nature. No official turn allocation takes place, however, every turn taken is respected, everyone has the right to speak. The researcher is not present during the taping of the meeting.

The analysis of the data was made using a transcription of the videotaped material. The original video data were used to help observe the physical surroundings, how the participants were situated in the room - to make sure to whom the speech was directed. Hence, the focus of the analysis was on the transcribed text material. The first part of the analysis consisted of dividing the data into different storylines by assorting what (and when) happens and takes place during the meeting. Using the basic concepts of the Positioning Theory, this was followed by the analysis of each storyline and utterance. Later, the storylines, and the positioning occurring within, were viewed with group processes - as I tried to identify what processes occurred and how they were connected with positioning.

\section{Results}

\section{Storylines Guiding the Positioning}

The meeting itself forms one sort of an institutional storyline, a mode of the joint interaction which is characterized by a certain time and place, order of business, institutional role of the participants, and the central role of the chairman (see e.g., Kangasharju 2002). After examining the progression of the meeting on a more general level, the meeting can be viewed as consisting of two larger phases - beginning of the meeting and discussion over the cases - both of which include different sub-phases. These two phases can be regarded as two largest storylines of the meeting. The storyline of discussing the cases can be divided into the following substorylines: presenting the case, discussing the case (argumentation), and making decisions about the case. Within these larger storylines are embedded diverse micro-level "sub-storylines" (e.g., only one or two utterances) in which the participants can negotiate new positions and form new storylines.

Positioning itself can be approached by its form and contents. The forms of positioning can be divided into three modes: first, second, and third order positioning. Acting according to the position defined by oneself or the others is called first order positioning. Second order positioning takes place when the position is not taken for granted and is questioned. Third order positioning, or accountive positioning occurs when a previous social episode is discussed and explained to someone outside the original episode (see Harré and van Langenhove 1999b).

The contents of different orders of positioning vary, depending on, for example, what the positioning is based on (moral and personal positioning), how the positioning is manifested (tacit or intentional positioning), or who is being positioned (positioning of the self or other) (see Harré and van Langenhove 1999b). The following examples demonstrate the basic forms of positioning which take place during the meeting.

\section{Storyline of Starting the Meeting}

Discussion over general topics, conventions, and general terms, as well as institutionally mediated 
information, such as the maximum and minimum amounts of the benefits, is characteristic to the storyline of starting the meeting. The first extract comes from the very beginning of the meeting - as everyone is taking the seat and settling down. ${ }^{2}$

\section{Speakers:}

D: Doctor

HSD(n): Home help service director (n)

$\mathrm{N}(\mathrm{n})$ : Nurse (n)

S: Secretary of care giving

\section{Fragment 1}

1 D: we should there are coming [st- $(-)$ meijän varmaan on tulossa $[\mathrm{vi}-(-)$ 2 HSD1:

Imutta

3 surely we will start [when it's already one o'clock kai me alotetaan $\quad[$ ku kello on jo yli yks 4 D: $\quad$ [let's start now yes and [alotetaan nyt joo ja

5 time goes on [so quickly on.

aika menee [niin kovasti kyytiä.

6 HSD1: [past one

[yli yksi

$7(0.5)$

8 we must these have to get dealt with so that we could meidän täytyy nää pakko saada käsiteltyä että saatais

This example aptly depicts the tacit first order positioning (position is not argued). The doctor suggests waiting for the last ones to arrive (line 1), but one of the home help service directors suggests to start the meeting immediately (lines 2-3) and thus, through her suggestion, becomes positioned as a kind of

Extracts presented in this paper include both an English translation and original Finnish citations. chairman of the meeting at hand. This positioning is instantly followed by accounts on the behavio (lines 6-8). The position is accepted by the others, in this case - by the doctor (line 4). Here, the positioning is the part of group interaction developement; it illustrates who has the right to start the meeting.

The next example follows the previous episode as one of the nurses gets up and leaves the room momentarily.

\section{Fragment 2}

19 N1: I will go still. I'll come mä käyn viel. mä tuun

$20 \quad(0.5)$

21 HSD2: I: will need this (( to someone else )) mää tarviisin tätä

22 N2: say at the [same time that they should come from

sano ny [samalla että ne tulevat

23 HSD2:

here (( to someone else )) [tähän

24N1:

The comment uttered by the nurse (N2, line 22) illustrates - from the positioning viewpoint - the right to tell and instruct the other nurse (N1). The extract demonstrates the first order positioning when one interlocutor is seen as someone who has the moral duty to order the other. The first order positioning is not denied and hence, it is not followed by the second order positioning (denying the first order positioning). Perhaps, in this case, the nurses positioning illustrates their relation to each other rath er than the relations concerning the whole group However, it depicts the role of positioning in the proceeding with interaction, as well as how a consensus is maintained. Imagine what would happen if the position was denied and challenged.

The following extract demonstrates the dynamic nature of positioning when - during only few utterances - adopted positions are questioned, yet, maintaining the status quo of the social order.

\section{Fragment 3}

57 S: they can already be (.) written (.) down otherwise ne voidaan jo (.) kirjata (.) ylös muuten

58 but that not before the board has,

mutta että sitten vasta kun lautakunta on

$59 \quad(0.5)$

60 S: so it should be tomorrow as far as I know elikkä sen pitäis olla huomenna mun käsittääksen

61 [the board meeting [lautakunnan kokous,

62 HSD3: [but the board is today [tänäänhän on lautakunta.

$63 \quad(0.2)$

$64 \mathrm{~S}: \quad$ \#well it might be any day now\# but I will put them to the \#no on se sitten minä päivänä tahansa\# mutta mä laitan ne sinne

memo as a reservation muistioon varauksena

The clarifying statement of the home help service director (HSD3, line 62) questions the secretary's expert position by means of second order positioning. Although the positioning does not take place in its essential proposal-question-form, the expert position adopted by the secretary can be regarded as the tacit first order positioning, and the home help service director's statement as intentional positioning. However, the secretary does not pay much attention to this and continues the interaction perpetuating her previous position after having briefly commented on home help service director's statement (line 64).

Especially the first and the second order positionings were typical for this storyline. These positions were mainly adopted by the tacit, moral, and deliberate first order positioning when the members' expectations and duties to others and self became apparent.

In this storyline, expert positions are adopted. The next example demonstrates how one of the home help service directors (HSD3) adopts an expert position via deliberate positioning of the self by clarifying the basic concepts used during the meeting.

\section{Fragment 4}

168 HSD3: I would suggest that I could read this what mä ehdottaisin että mä voisin lukee tän mistä se

$169 \quad(0.5)(-)$ the need for nursing consists of? (0.5) ( - ) muodostuu se hoidettavuus?

$170 \quad[\mathrm{~mm}$

171 [and then the limits do we know what we have [ja sitten ne rajat onko meille selvillä mitkä me ollaan 172 always .hh made about the caregiver nurse aina .hh tehty omaishoitajasta

173 .hhh so the clear limit [partition would be hhh nin ne selkeet rajan [jaot kyllä ois varmaan yes $[\mathrm{kyllä}$

175 [good to [revise [hyvä [kerrata

$176 \quad$ [yes [joo

$177 \quad$ [yes

[jo

kertaas 
Not only adopting a position but also receiving one is included in the example. The deliberate first order positioning (HSD3) is confirmed by others and the second order positioning and thus, the need for accounts does not become necessary. Again, the positions designed for oneself and others are imperceptibly present within the speechact, but, after a closer look, they become obvious. The utterances of the home help service director (HSD3) show that she has the right to position herself as an expert in regard to the basic concepts of nursing. At once, the chairman position moves to this home help service director. Now, the processes of positioning help to clarify the concepts used by the group by enhancing shared understanding.

\section{The Storyline of Case Discussion}

In the storyline of discussing the particular cases, one client's state of health, entitling this client to the given amount of home care benefits, is introduced and discusses. This storyline makes certain positions evident as everyone in the meeting has a specific duty and role - some as experts, some as listeners and commentators.

This storyline includes the third order positioning, which refers to discussion about events and persons outside the meeting. Normally, the third order positioning occurs while referring to the episode that has already taken place (van Langenhove and Harré 1999:21), nonetheless, in this case, speaking about the client is also seen as the third order positioning since the clients are not physically present at the meeting and cannot, therefore, deny the positions appointed to them.

\section{Fragment 5}

$2332 \mathrm{D}$ : and this kind of sta- stiff and stagnant ja tämmönen pys- jäykistyny ja pysähtyny, $2333 \quad(1.0)$

2334 still picture and here has needed h- help pysähtyny kuva ja tässä on tarvinnu a- apua

2335 in particular .uh with moving washing up nimenomaan .hh ihan liikkumisessa peseytymisessä

2336 getting dressed, $(0,5)$ help in the toilet in bed can't pukeutumisessa, $(0,5)$ veeseessä apua ei voi

2337 turn around independently must be turned over during the night and omatoimisesti kääntyä yöllä käänneltävä ja

2338 wears a diaper during the night. vaippa yöllä.

2339 HSD3: yes. .uh so that is true and about the kyllä. .hh eli toi pitää paikkansa ja siitä 2340 moving around that he doesn't move around independently anymore liikkumisestä sen verran että hän ei liiku enä yhtään itsenäisesti

This example demonstrates how the doctor adopts the position of an expert by the means of the tacit first order positioning. The expert position is build up as the doctor clarifies the current state of the client; the third order positioning of the client requires the doctor's expertise - his expert position. In this case, the client is positioned as a person who has difficulties in independent functioning. The home help service director (HSD3) approves this position (lines 2339-2340), as well as the doctor's depiction of the client, and add some details to the client's description, what helps her to adopt the position of an expert-by means of the tacit first order positioning.

Similar positioning occurs in almost every case presentation when the backgrounds and the cur- rent states of the clients are examined and the position of an expert and a chairman is shared with the doctor by the person who - most recently - has been in contact with the presented client. This demonstrates the dynamic shifts of positions within the group. However, in this storyline, and especially while proceeding from one client to another, different kinds of positioning come about.

\section{Fragment 6}

837 D: well next (client's name)?

$$
\text { no seuraavana (asiakkaan nimi)? }
$$

838 S: erm hey hey [hey hey

$$
\text { tota hei hei [hei hei }
$$

$839 \mathrm{D}$

$$
\begin{aligned}
& \text { [sorry, } \\
& \text { [anteeks, }
\end{aligned}
$$

840 S: so this had the right to free.

ni tällä oli oikeus vapaaseen.

The doctor wants to discuss the next case (line 837), but the secretary interrupts (line 838 ) by getting back to the previous one. This exemplifies the secretary's right to interrupt the doctor because of the unfinished matter. This happens according to the first order positioning and the position attributed to oneself is accepted. After this episode, each time before passing to the new case, the doctor asks, if the secretary approves it. Clearly, the doctor has not got the right to do so without the secretary's permission. This positioning entirely alters the course of interaction at hand.

The next extract demonstrates both the conflict and positioning in the storyline. One of the home help service directors (HSD1) and the secretary (S) have been discussing a client's right to some services, but did not agree over that matter.
Fragment 7

970 HSD1: yes I know but there was a $\downarrow$ change also thi

kyllä mää tiedän mutta kun siihen tuli $\downarrow$ muutos tänä vuonnakin

97 when all the clients made calls [from

everywhere.]

ku asiakkaat soitteli_ [joka puolelta.] [yes but I don't

know] that are there any coming [joo mut mä en

tiedä] että onko nyt tulossa [and what changes (are they) [going to the boar [ja mitä muutoksia (ne on) [lautakuntaan

menossa

\section{HSD1: [( - ) alright.}

$$
\text { [( - ) selvä. }
$$

975

[so then there is no [elikkä ei oo sitten

976 since there's a daycare center [once a week. koska tääl on päiväkeskus [kerran viikossa. 977 ${ }^{\circ}{ }^{\circ}{ }^{\circ} a h^{\circ}$ ['just ${ }^{\circ}$

978 HSD3: but that doesn't influence the admission of service coupons

mutta sehän ei vaikuta palvelusetelien myöntämiseen

979 he statutory [leave, se lakisääteinen [vapaa,

980

981 HSD3:

\section{[yes they are two different [things} [niin ne on kaksi eri [asiaa

$982 \mathrm{~S}: \quad$ [statutory and service voucher, [lakisääteistä ja palvelusetelia,

983 HSD3: [can be admitted even ] if there is no [saa myöntää silti ] vaikka ei oo 
This example demonstrates the disagreement - between one of the home help service directors and the secretary - regarding the case at hand as the secretary comments on the home help service director's statement in a harsh way (lines 972-973, 980, and 982). Now, the other expert on the case (HSD3) adopts the position of a negotiator (lines 978-979, 981, and 983) - a position in which the doctor has previously acted - and tries to clarify the issue for the other home help service director by asking the question - so that a consensus could be achieved between the secretary and the other director. At the same time, the sub-storyline of disagreement changes into the tutorial one. These kinds of sub-storylines take place within the larger storyline of the meeting and describe the specific nature of the situation in which the ongoing interaction is embedded.

\section{Discussion}

All forms of positioning occurred during the meeting at hand. The positioning - of oneself and others - was often either tacit or intentional. One central form of positioning, describing the contents of the positions, was moral positioning which occurred on both the first and the third order level. In this case, the basis for positioning was the team members' duties to act in a certain way - according to their knowledge and skills, simultaneously articulating one's expertise.

More "discreet" shifts in storylines also were observable during the meeting. These micro-level sub-storylines were included in the ongoing phases or storylines, such as the storyline of argumentation. One example is the situation when the secretary and the home help service director (HSD1) disagree about the client's right to a certain benefit. The storyline quickly changes from the argumentative to tutorial one as the other home help service director (HSD3) assumes the position of a negotiator and thus, ascertains grounds for both her and the secretary's answer. Therefore, adopting a certain position is intertwined with stating a disagreement and finding a solution in a most intriguing and remarkable way.

The positioning occurring during the meeting under scrutiny can be viewed as dualistic. At the same time, it can be understood in relation to the positions adopted, or created, during the course of interaction (positions such as chairman or expert), as well as from the view point of different forms of positioning (first, second, and third order positioning)

But, what makes the positioning accruing in a group different from the interpersonal positioning between two people? One prominent difference is constituted by the perlocutionary effects of the speech-acts. In this case, the adopted and suggested positions, as well as how the group members respond to them, impact upon the way the whole group functions. For instance, in extract six (Fragment 6), the perlocutionary effect of the secretary's speech-act influences the group and changes the way the interaction at hand proceeds. Also, the roles and the status of the group members influence, for sure, the understanding of what kinds of positions are possible and who is obligated or responsible to take part in the interaction. These issues might be more visible, and present, within a group setting than interpersonal settings.

This study shows both the significance and the role positioning play in the small group interac- tion. In this case, positioning was studied within the context of group processes and interactional phenomena of the group, varying from the progression of the meeting (Fragment 1, 2, 4) to the clarification of shared concepts (Fragment 3), argumentation and decision-making (Fragment 5), possible manifestation of conflicts, and conflict resolution (Fragment 7), as well as making change happen (Fragment 6).

Only the transcribed material of the interaction and speech-acts was analyzed in this study, leaving out the analysis of the videotaped material. This was done for two reasons. First, the videotaped material consists of data recorded by the camera that was located in the corner of the meeting room Consequently, some participants are facing away from the camera, what would possibly make the analysis of, for instance, non-verbal communication very difficult. Second, and more importantly, in approaching the group behavior from a Harréan positioning point of view, the multimodal or nonverbal elements of interaction are not relevant. The adaptation of these standpoints makes the analysis focused on verbal communication, as well as joint construction of the situation and positions via speech-acts. This, however, can be regarded as a weakness of the approach at hand as the inclusion of viewpoints from the video-based analysis could offer additional insights to the positioning processes. Advances in the visual ethnography and the analysis of videotaped materials (see e.g., Pink 2007; Heath, Hindmarsh, and Luff 2010), as well as the developments in the analysis of the multimodalities of interaction (see e.g., Jones and LeBaron 2002; MacMartin and LeBaron 2006), have made it possible to analyze interactions in a more detailed way, focusing also on the embodiment, physical surroundings, and artifacts involved in the everyday interaction.

One of the aims of this study was to explore the possibilities of applying the basic concepts and ideas of the Positioning Theory as a means to analyze small group interaction. But, why is it important to study small groups from a micro-cultural perspective? One possible answer derives from the everyday life of diverse organizations. Since the explicit structures of power, and related role expectations, have changed in the aftermath of transition from bureaucratic to post-bureaucratic models of organizations, the guidelines influencing individual behavior are more negotiable and flexible (see e.g., Webb 2004).

One's objectives and functioning within an organization are now conducted, for the most part, by individuals. Hence, the definition of a subordinate's position, as part of organization power structures and social order, is achievable and negotiable in the course of everyday interactions. Accordingly, the studies focusing on how and in what contexts these positions are achieved and how one's place in the social order is negotiated have become relevant.

The present study illustrates the dynamic and shifting nature of small group interaction, highlighting the need for elaborated and detailed research in this field. The empirical analysis of small group interaction demonstrates how people - fluently and effortlessly - negotiate their positions amongst each other and how proficiently they take part in the interaction that both creates and guides the small group's functioning. It also demonstrates the microcultural nature of the group at hand, which have its 
own manners and morality that are continuously negotiated. The group in question also has very specific methods and phases of working together, something that is observable due to the application of the Positioning Theory, in this case - the concept of storylines. The acts of positioning demonstrate the dynamic nature of negotiating identities; again, something what is very typical within the micro-cultural group studies context. In addition, the standpoints and basic concepts of the theory at

\section{References}

Arminen, Ilkka. 2005. Institutional Interaction: Studies of Talk at Work. Burlington, VT: Ashgate.

Asmuß, Birte and Jan Svennevig. 2009. “Meeting Talk: an Introduction." Journal of Business Communication 46(1):3-22.

Bales, Robert F. 1951. Interaction Process Analysis: a Method for the Study of Small Groups. Cambridge: Addison-Wesley Press.

Burke, Peter J. 2003. "Interaction in small groups." Pp. 363-387 in Handbook of Social Psychology, edited by John Delamater. New York: Kluwer Academic

Delamater, John, (ed.). 2003. The Handbook of Social Psychology. New York: Kluver Academic.

Denzin, Norman K. 1999. "Reading the interaction order." Pp. 285-312 in Social psychology, $8^{\text {th }}$ ed., edited by Alfred R. Lindesmith, Anselm L. Strauss, and Norman K. Denzin. London: Sage.

Firth, Alan, (ed.). 1995. The Discourse of Negotiation. Studies of Language in the Workplace. Oxford: Pergamon.

Frosh, Stephen, Ann Phoenix, and Rob Pattman. 2003. "Taking a Stand: Using Psychoanalysis to Explore the Positioning of Subjects in Discourse." British Journal of Social Psychology 42(1):39-53. Retrieved April 10, 2011 (http:// eprints.bbk.ac.uk/101/1/frosh6.pdf). hand offer a methodological tool which is suitable for the analysis of small group interactions, as well as for the examination of the linguistic and microcultural scopes of small group dynamics.

\section{Acknowledgements}

I would like to thank Professor Pirjo Nikander for the opportunity to use the data utilized in this study.

Gough, Brendan and Majella McFadden. 2001. Critical Social Psychology: An Introduction. New York: Palgrave Macmillan.

Harré, Rom. 1997. “Social life as rule-governed patterns of joint action." Pp. 129-145 in The Message of Social Psychology: Perspectives on Mind in Society, edited by Craig McGarty and Alexander Haslam. Oxford: Blackwell Publishers.

Harré, Rom and Fathali Moghaddam, (eds.). 2003. "Introduction: the self and others in ttraditional psychology and in positioning theory." Pp. 1-11 in The Self and Others: Positioning Individuals and Groups in Personal, Political, and Cultural Contex. Westport, CT: Praeger.

Harré, Rom and Fathali Moghaddam. 2008. "Intrapersonal conflict." Pp. 65-78 in Positioning Theory: Moral Contexts of Intentional Action, edited by R. Harré and Luk van Langenhove. Oxford: Blackwell Publishers.

Harré, Rom and Nikki Slocum. 2003. "Disputes as complex social events: on the uses of the positioning theory." Pp. 123-136 in The Self and Others: Positioning Individual and Groups in Personal, Political, and Cultural Context, edited by Rom Harré and Fathali Moghaddam. Westport, CT: Praeger.

Harré, Rom and Luk van Langenhove, (eds.). 1999a. Positioning Theory. Oxford: Blackwell Publishers.
Harré, Rom and Luk van Langenhove, (eds.). 1999b. "The dynamics of social episodes." Pp. 1-13 in The Positioning Theory. Oxford: Blackwell Publishers.

Hartley, Peter. 1997. Group Communication. London: Routledge.

Heath, Christian, Jon Hindmarsh, and Paul Luff. 2010. Video in Qualitative Research. London: Sage.

Heritage, John. 2004. “Conversation analysis and institutional talk." Pp. 103-146 in Handbook of Language and Social Interaction, edited by Robert Sanders and Kristine Fitch. Mahwah NJ: Lawrence Erlbaum Associates.

Hydén, Margareta. 2005. “I Must Have Been an Idiot to Let It Go On': Agency and Positioning in Battered Women's Narratives of Leaving." Feminism Psychology 15(2):169-188.

ones, Stanley E. and Curtis D. LeBaron. 2002. “Research on the Relationship Between Verbal and Nonverbal Communication: Emerging Integrations." Journal of Communication 52(3):499-521.

Kangasharju, Helena. 2002. "Alignment in Disagreement: Forming Oppositional Alliances in Committee Meeting." Journal of Pragmatics 34(10/11):1447-1471

Linehan, Carol and John McCarthy. 2000. “Positioning in Practice: Understanding Participation in the Social World." Journal for the Theory of Social Behavior 30(4):435453. Retrieved April 10, 2011 (http://onlinelibrary.wiley. com/doi/10.1111/1468-5914.00139/pdf).

MacMartin, Clare and Curtis D. LeBaron. 2006. "Multiple Involvements Within Group Interaction: A Video-Based Study of Sex Offender Therapy." Research on Language \& Social Interaction 39(1):41-80.

Moghaddam, Fathali, Elizabeth Henley, and Rom Harré. 2003. "Sustaining intergroup harmony: An analysis of the Kissinger papers through positioning theory." Pp. 137-156 in The Self and Others: Positioning Individuals and Groups in Personal, Political, and Cultural Context, edited by Rom Harré and Fathali Moghaddam. Westport, CT: Praeger.

Moura, Georgina de et al. 2008. "Prospects for Group Processes and Intergroup Relations Research: a Review of 70 Years' Progress." Group Processes \& Intergroup Relations 11(4):575-596. Retrieved September 15, 2011 (http:// gpi.sagepub.com/content/11/4/575.full.pdf+html).

Nikander, Pirjo. 2003. “The absent client: Case description and decision-making in inter-professional meetings." Pp. 112-128 in Constructing Clienthood in Social Work and Human Services: Identities, Interactions and Practice, edited by Christopher Hall et el. London: Jessica Kingsley Publishers.

Nikander, Pirjo. 2005. “Managing scarcity: Joint decision making in inter-professional meetings." Pp. 260-279 in Social Work in Health and Mental Health: Issues, Developments and Actions, edited by Tuula Heinonen and Anna Metteri. Toronto: Canadian Scholars' Press.

Pink, Sarah. 2007. Doing Visual Ethnography. London: Sage.

Poole, Marshall S. and Andrea B. Hollingshead. 2004 Theories of Small Groups: Interdisciplinary Perspectives. Thousand Oaks, CA: Sage.

Poole, Marshall S. et al. 2004. "Interdisciplinary Perspectives on Small Groups." Small Group Research 35(3):3-16. Retrieved March 15, 2011 (http://sgr.sagepub.com/content/35/1/3.full.pdf+html).

Potter, Jonathan and Derek Edwards. 2001. "Discursive social psychology." Pp. 103-118 in The New Handbook of Language and Social Psychology, edited by Peter W. Robinson and Howard Giles. London: Wiley.

Potter, Jonathan and Margaret Wetherell. 1987. Discourse and Social Psychology: Beyond Attitudes and Behaviour. London: Sage.

Rohall, David E, Melissa A. Milkie, and Jeffrey W. Lucas. 2007. Social Psychology. Sociological Perspectives. Boston Allyn and Bacon.

Sammut, Gordon and George Gaskell. 2010. "Points of View, Social Positioning and Intercultural Relations." Journal for the Theory of Social Behaviour 40(1):47-64. Retrieved April 10, 2011 (http://onlinelibrary.wiley.com/ doi/10.1111/j.1468-5914.2009.00422.x/pdf)

Schmidle, Robert E. 2010. "Positioning Theory and Terrorist Networks." Journal for the Theory of Social Behaviour 
40(1):65-78. Retrieved April 8, 2011 (http://onlinelibrary. wiley.com/doi/10.1111/j.1468-5914.2009.00421.x/pdf).

Schwartzman, Helen B. 1989. The Meeting: Gatherings in Organizations and Communities. New York, London: Plenum Press.

Slocum-Bradley, Nikki. 2010 “The Positioning Diamond: A Trans-Disciplinary Framework for Discourse Analysis." Journal for the Theory of Social Behaviour 40(1):79-107.

Retrieved April 8, 2011 (http://onlinelibrarywwileycom/ doi/10.1111/j.1468-5914.2009.00418.x/pdf). van Langenhove, Luk and Rom Harré, (eds.). 1999. "Introducing positioning theory." Pp. 14-31 in Positioning Theory. Oxford: Blackwell Publishers.

Webb, Janette. 2004. "Organizations, Self-Identities, and the New Economy." Sociology 38(4):719-738.

Wittenbaum, Gwen M. and Richard L. Moreland. 2008. "Small-Group Research in Social Psychology: Topics and Trends Over Time." Social and Personality Psychology Compass 2(1):187-203. Retrieved March 15, 2011 (http://onlinelibrary.wiley.com/doi/10.1111/j.1751-9004.2007.00065.x/pdf).

\section{Appendix 1}

List of transcription symbols.

micro-pause (less than 0.3 seconds)

(0.5) pause (duration)

[ ] overlapping speech

$\downarrow \uparrow \quad$ onset of noticeable pitch rise or fall

o o quiet speech

( ) a guess of what might have been said if unclear

(-) unclear talk

even intonation

intonation falls to low

intonation rise to high

creaky voice

speaker emphasis

so- $\quad$ sharp cut-off of the prior word or sound

(( )) transcriber's note Peview 9(4):100-114. Retrieved Mont (http://www.qualitativesociologyreview.org/ENG/archive_eng.php) 